\title{
Acaricidal activity of ethanolic extract from aerial parts of Tagetes patula L. (Asteraceae) against larvae and engorged adult females of Rhipicephalus sanguineus (Latreille, 1806)
}

Flávio Augusto Sanches Politi ${ }^{1}$, Glyn Mara Figueira², Andréa Mendez Araújo ${ }^{3}$, Bruno Rodrigues Sampieri ${ }^{3}$ Maria Izabel Camargo Mathias ${ }^{3}$, Matias Pablo Juan Szabó ${ }^{4}$, Gervásio Henrique Bechara ${ }^{5}$,

Lourdes Campaner dos Santos ${ }^{6}$, Wagner Vilegas ${ }^{6}$ and Rosemeire Cristina Linhari Rodrigues Pietro ${ }^{1^{*}}$

\begin{abstract}
Background: The tick Rhipicephalus sanguineus is the species with the largest worldwide distribution and is proven to be involved in the transmission of pathogens such as Babesia canis, Ehrlichia canis, Coxiella burnetii, Rickettsia ricketsii, Rickettsia conorii, among others. Studies have demonstrated acquisition of resistance to some of the active principles used in commercial formulations of acaricides. Tagetes patula (Asteraceae) is a plant with highlighted economic and commercial importance due to the production of secondary metabolites with insecticide and acaricide potential, mainly flavonoids, thiophenes and terpenes.

Methods: The in vitro acaricide action of the ethanolic 70\% extract from aerial parts of T. patula, obtained by percolation, was evaluated against larvae and engorged adult females of Rhipicephalus sanguineus by immersion test for 5 minutes. The chemical characterization of this extract was done by liquid chromatography coupled with mass spectrometry (LC-MS), using direct injection of sample.

Results: Despite T. patula not proving lethal to adults in any of the concentrations tested, at $50.0 \mathrm{mg} / \mathrm{mL}$ oviposition rate decreased by $21.5 \%$ and eliminated $99.78 \%$ of the larvae. Also it was determined that the best results were obtained with 5 minutes of immersion. From the chromatographic analysis twelve O-glycosylated flavonoids were identified.
\end{abstract}

Conclusions: This is the first report on the acaricidal activity of T. patula extract against Rh. sanguineus. If we consider the application of the product in the environment, we could completely eliminate the larval stage of development of the ixodid Rh. sanguineus.

Keywords: Tagetes patula, Rhipicephalus sanguineus, flavonoids, mass spectrometry, adult immersion test, larval immersion test

\footnotetext{
* Correspondence: pietrorc@fcfar.unesp.br

${ }^{1}$ Department of Drugs and Medicines, School of Pharmaceutical Sciences,

UNESP - Univ Estadual Paulista, Rodovia Araraquara-Jaú, Km 01, SP,

Araraquara CEP 14801-902, Brazil

Full list of author information is available at the end of the article
} 


\section{Background}

The intense agricultural activity, the interaction of man and domestic animals and the recent background of climate change in the world favor the spread of infectious agents transmitted by ticks, leading to the emergence and resurgence of different etiologic agents [1].

The subclass Acari, class Arachnida, which belongs to ticks and other mites, is a very heterogeneous group presenting great diversity of habits and habitats [2]. Ticks are inserted in the order Ixodida, which can be divided into three families: Argasidae, Ixodidae and Nuttalliellidae. The tick Rhipicephalus sanguineus (Latreille, 1806) is the species currently with the most worldwide spread, due the wide distribution of its natural host, the dog, and also due to nidicolous habits [3]. It is related to the transmission of pathogenic agents, mainly Babesia canis and Ehrlichia canis [4-6]. The parasite can also transmit several Rickettsia species to man, such as Rickettsia rickettsii and $R$. conorii, the causative agents, respectively, of Rocky Mountain spotted fever in Mexico and South America, and Botonous Fever in the Mediterranean region of Southern Europe and Northern Africa [7]. Fipronil, amitraz, carbaryl and pyrethroids (deltamethrin, permethrin and cypermethrin) are the acaricides most employed for its control [8-13], however, some authors have reported resistance of ticks to commercial formulations containing these compounds [14]. The use exclusive of synthetic products is becoming less viable in practical and economic terms, since its indiscriminate use causes environmental pollution, toxicity to humans and the appearance of chemical residues in products of animal origin [15]. When thinking about the control of $R h$. sanguineus ticks, it must be considered that only $5 \%$ are found on dogs and the other $95 \%$ are free in the environment. Therefore, its effective elimination will require an integrated control strategy, aimed at both the canine population and the environment $[16,17]$.

Plant extracts can be used to control certain species of ticks such as Hyalomma anatolicum excavatum [18], Amblyomma americanum, Dermacentor variabilis [19] and even Rh. sanguineus [20-23]. Among the advantages of phytotherapics that currently justify their use are the synergistic effects of its compounds, the combination of mechanisms for substances acting on different molecular targets, the lowest risk of side effects and lower costs in research [24].

Tagetes patula L. (Asteraceae), popularly known as dwarf marigold or French marigold, is an annual plant with $20-30 \mathrm{~cm}$ height, native to North America and widely disseminated worldwide [25]. Its flowers have varied coloration, and may present yellow petals, orange or a mix of these two shades. Is easily cultured and propagated, producing flowers and seeds throughout the year, with high germination rates. The phytochemical investigation of different parts of T. patula has resulted in the isolation of the chemical constituents of several classes of secondary metabolites, such as flavonoids, benzofurans, carotenoids and thiophenes, the latter being responsible for a variety of biocidal effects [26]. Bano et al. [27], from different parts of T. patula (roots, leaves and flowers) isolated and characterized by spectroscopic methods, several thiophenes, steroids and terpenoids: $5^{\prime}$ - hydroxymethyl-5-(3-butene-1-ynil)-2,2'-bithiophene; methyl-5-[4-(3- methyl-1- oxobutoxy)-1-butynyl]-2,2' bithiophene; cholesterol; $\beta$-sitosterol (24-R-stigmast-5ene-3 $\beta$-ol) (4); stigmasterol [24-(S)-stigmast-5,22E-dien$3 \beta-o l]$ and lupeol. Flavonoids, such as kaempferol and quercetina, were reported by Ivancheva and Zdravkova [28]. Tarpo [29-31] and Bhardwaj et al. [32], recorded the presence of patuletin-7-O-glucoside (patulitrin), patuletin, quercetagetin, quercetagetin-7-O-glucoside and luteolin in petals of T. patula.

This study aimed to perform the chemical characterization by high pressure liquid chromatography coupled to mass spectrometry (HPLC-MS) of the 70\% ethanolic extract from aerial parts of $T$. patula and test the acaricidal action in larvae and engorged adult females of Rh. sanguineus through immersion tests for 5 minutes.

\section{Methods}

\section{Plant material}

Aerial parts of Tagetes patula (stems, leaves and flowers) were obtained through an agreement signed with the Collection of Medicinal and Aromatic Plants (CPMA) of the Multidisciplinary Center for Chemical, Biological and Agricultural Research (CPQBA), Universidade Estadual de Campinas (UNICAMP). The planting was done in a total area of $100 \mathrm{~m}^{2}$, from seeds of Top Seed Garden line $\left(\right.$ Agristar $\left.^{\circledR}\right)$. The harvesting occurred in June 2010. A voucher specimen was deposited under number 1421 in the CPQBA Herbarium.

\section{Sample preparation}

After the stabilization and drying, the aerial parts of the plant were triturated into cutting mill. The powdered drug was used for preparing the extract by percolation using ethanol $70 \%(\mathrm{v} / \mathrm{v})$ as the extractor liquid, with average flow rate of 40 drops/minute. After complete evaporation of the solvent, this extract was lyophilized and stored in a desiccator to avoid incorporating humidity and/or contamination.

For the chemical characterization by liquid chromatography coupled to mass spectrometry, the extract was solubilized in $\mathrm{MeOH}$ (Baker ${ }^{\circledR}, \mathrm{HPLC}$ grade) to give a solution $1.0 \mathrm{mg} / \mathrm{ml}$, which was filtered in expanded polytetrafluoroethylene membrane (PTFE) with pores of $0.45 \mu \mathrm{m}$. The final solution was introduced directly into 
the ESI source using a glass syringe boosted by a pumping system with outflow of $20.0 \mathrm{~mL} / \mathrm{min}$.

The solution used in the Adult Immersion Test (AIT) and Larval Immersion Test (LIT) was prepared using Triton-X-100 1.25\% (v/v), because ethanol proved toxic in preliminary tests. Serial dilution was prepared so as to obtain test solutions $12.5,25.0,50.0$ and $100.0 \mathrm{mg} / \mathrm{mL}$.

\section{Collection of ticks}

Engorged adult females of Rh. sanguineus were obtained from the colony of the Brazilian Centre of Studies on Tick Morphology (BCSTM), Universidade Estadual Paulista "Julio de Mesquita Filho" (UNESP), Instituto de Biociências (IB), Rio Claro (SP), maintained under controlled conditions $\left(27-28^{\circ} \mathrm{C}, 70-80 \% \mathrm{RH}, 12 / 12 \mathrm{~h}\right.$ photoperiod) in BOD incubator (Eletrolab EL 202/3). These ticks were fed in fabric chambers on the dorsum of New Zealand white rabbits (Oryctolagus cuniculis) [approved by the ethics committee on the use of animal (CEUA), IB-UNESP, protocol number 026/2011], according to the procedure described by Bechara et al. [33].

\section{Mass spectrometry}

The mass spectra of the ethanolic 70\% extract of aerial parts of T. patula were obtained on a HPLC coupled to a mass spectrometer LCQ Fleet (Thermo Scientific ${ }^{\circledR}$ ), equipped with a dispositive of direct insertion of the sample via flow injection analysis (FIA). The studied matrix was analyzed by electrospray ionization (ESI) and the fragmentation in multiple stages $\left(\mathrm{MS}^{2}, \mathrm{MS}^{3}, \mathrm{MS}^{\mathrm{n}}\right)$ was performed at an ion trap (IT) interface. The negative mode was selected for the generation and analysis of the mass spectra for the first order (MS), and for the remaining experiments in multiple stages $\left(\mathrm{MS}^{\mathrm{n}}\right)$ under the following conditions: capillary voltage $-25 \mathrm{~V}$, voltage spray $-5 \mathrm{kV}$, capillary temperature $275^{\circ} \mathrm{C}$, carrier gas nitrogen $\left(\mathrm{N}_{2}\right)$ with a flow of 8 arbitrary units (A.U.), collision gas helium (He). The track acquisition was 100 $2000 \mathrm{~m} / \mathrm{z}$. The software Xcalibur version 1.3 (Thermo Finigan ${ }^{\circledR}$ ) was used to acquire and process data.

\section{Adult Immersion Test (AIT)}

Groups of 10 Rhipicephalus sanguineus engorged females, chosen randomly, were immersed for 5 minutes in Petri dishes ( $5.5 \mathrm{~cm}$ diameter, $1.5 \mathrm{~cm}$ high) containing $10.0 \mathrm{~mL}$ of the respective dilutions of $70 \%$ ethanolic extract from aerial parts of T. patula $\left(\mathrm{AP}_{\mathrm{EtOH} 70 \%}\right): 12.5,25.0,50.0$ and $100.0 \mathrm{mg} / \mathrm{mL}$, using a solution of Triton X-100 1.25\% $(\mathrm{v} / \mathrm{v})$ as negative control. The ticks were removed from solution, dried on paper towels and gently allocated individually in sterile 24 -well plates, incubated at $27-28^{\circ} \mathrm{C}$ and $70-80 \%$ RH (12/12 h photoperiod) in a BOD incubator. After two weeks it was determined the number of females laying eggs. The eggs were collected, weighed and then placed in glass tubes, which were incubated under the same conditions described above [34].

The calculation of the percentage of egg laying inhibition was performed according to equations [35]:

$$
\begin{aligned}
& \text { IE (index of egg laying) } \\
& \quad=\frac{\text { weight of eggs laid }(\mathrm{g})}{\text { weight of females }(\mathrm{g})}
\end{aligned}
$$

$$
\begin{aligned}
& \text { Egg laying inhibition }(\%) \\
& =\frac{[\mathrm{IE}(\text { control })-\mathrm{IE}(\text { treated group })] \times 100}{\mathrm{IE}(\text { control })}
\end{aligned}
$$

At the end of the third week the larval hatching rate was estimated, performing the count using a stereoscope. The efficiency of the extract was calculated according to the equations proposed by Drummond et al. [36]:

$R E=\frac{[\text { weight of eggs }(\mathrm{g}) \times \text { percentage of hatching } \times 20,000 *]}{\text { weight of female }(\mathrm{g})}$

$$
P E=\frac{[R E(\text { control group })-R E(\text { treated group }) \times 100]}{R E(\text { control group })}
$$

Where: $\mathrm{ER}=$ reproductive efficiency; $=\mathrm{EP}$ product efficiency; $"$ number of larvae at approximately $1.0 \mathrm{~g}$ of eggs (number experimentally obtained).

\section{Kinetics of action of the extract $\mathrm{AP}_{\mathrm{EtOH} 70 \%}$ in the adult immersion test}

In order to determine the correspondence of the exposure time of ticks in the test solution with the results obtained, the Adult Immersion Test with engorged females in $70 \%$ ethanolic extract from aerial parts of $T$. patula $(50.0 \mathrm{mg} / \mathrm{ml})$ for $5,10,30$ and 60 minutes was used. The test conditions were identical to those described above for $t=5$ minutes. Results represent the average of two assays, with groups containing five ticks each.

\section{Larval Immersion Test (LIT)}

The test was performed in triplicate following the protocol proposed by Shaw [37] with modifications. Approximately $0.01 \mathrm{~g}$ of eggs were placed individually in little bags of TNT fabric $(6.0 \mathrm{~cm} \times 6.0 \mathrm{~cm})$ and incubated in a BOD incubator at $27-28^{\circ} \mathrm{C}$ and $70-80 \% \mathrm{RH}(12 / 12 \mathrm{~h}$ photoperiod) for three weeks. After this period of hatching, approximately 200 viable larvae were collected and transferred to new bags. The procedure was to place the contents of the package, previously cooled to $-8^{\circ} \mathrm{C}$ for 1 minute, in the center of a Petri dish, kept above a vessel containing water and detergent, to prevent the escape 
of larvae in the laboratory. Under the effect of low temperature to which they were subjected, the larvae remained temporarily paralyzed, allowing their relocation. These new bags containing the larvae were immersed for 5 minutes in Petri dishes with $20.0 \mathrm{ml}$ of the respective dilutions of the extract $\mathrm{AP}_{\mathrm{EtOH} 70 \%}$ : 12.5, 25.0, 50.0 and $100.0 \mathrm{mg} / \mathrm{mL}$, using distilled water as negative control. Then, the bags were left on the filter paper until completely dry. Following this procedure, the bags were incubated at $27-28^{\circ} \mathrm{C}$ and $70-80 \% \mathrm{RH}(12 /$ $12 \mathrm{~h}$ photoperiod) for 48 hours (Figure 1). Live and dead larvae were counted to calculate the mortality rate, corrected according to Abbott's formula [38], recommended by the Food Agriculture Organization of the United Nations (FAO) [39]: concentrations (LC) to kill $50 \%$ and $99 \%$ of larvae and their respective $95 \%$ confidence intervals (CI) were calculated by probit analysis.

\section{Results}

The second order fragmentation (MS/MS) for each of the most representative ions led to the identification of secondary metabolites, observing the presence of flavonoids $O$-glycosides (Table 1 ), very common in the genus Tagetes [40-44]. Figure 2 shows the mass spectrum of the $70 \%$ ethanolic extract of the aerial parts of $T$. patula $\left(\mathrm{AP}_{\mathrm{EtOH} 70 \%}\right)$ obtained by direct injection in negative ionization mode $\left(\mathrm{m} / z[\mathrm{MH}]^{-}\right)$.

Peak 1 showed the signal of a deprotonated molecule $\left.{ }^{\mathrm{MH}}\right]^{-}$in $\mathrm{m} / \mathrm{z} 285$. The fragmentation of second order

$$
\% \text { Mortality }(\text { corrected })=\frac{[\% \text { Mortality }(\text { test group })-\% \text { Mortality }(\text { control group })]}{[100-(\%) \text { Mortality }(\text { control group })] \times 100}
$$

\section{Statistical analysis}

All statistical analyses were performed with StatPlus 2009 software (Soft Analyst ${ }^{\circledR}$ ). Results in Adult Immersion Test (mortality, egg laying inhibition, percentage of hatching, product efficiency, among other parameters) were analyzed by Sheffé, Tukey-Kramer and Neuman-Keuls tests (significance level: $\mathrm{p}<0.05$ ). Lethal was not stable, however, from the analysis of the fragments presented in full scan spectra $\left(\mathrm{MS}^{2}\right)$, the retroDiels-Alder reaction (RDA) could be observed, with pattern of fragmentation of ions at $\mathrm{m} / \mathrm{z} 151$ and at $\mathrm{m} / \mathrm{z} 134$, suggesting that this substance is kaempferol [45].

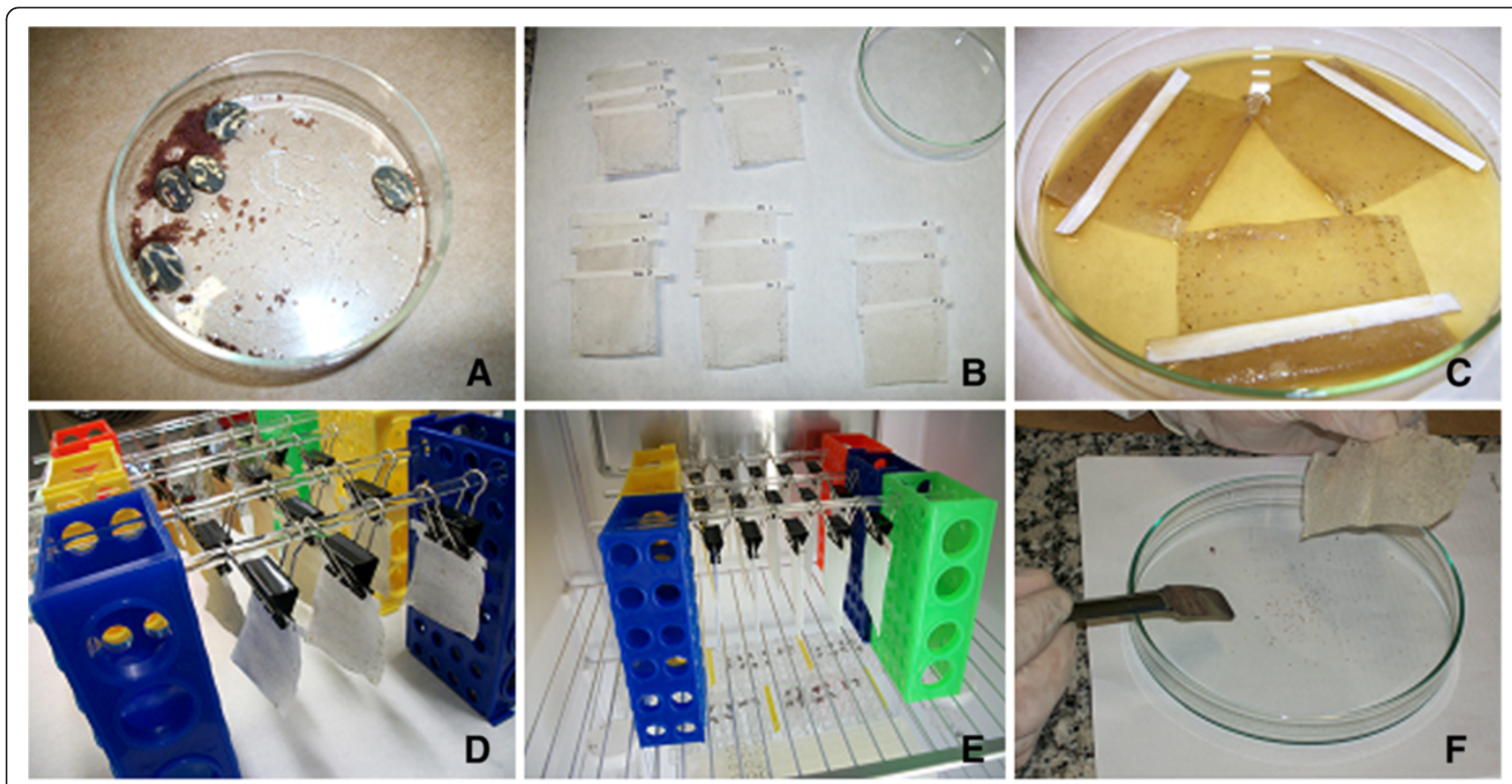

Figure 1 Experimental procedure for the Larval Immersion Test. (A-B) Approximately $1.0 \mathrm{~g}$ of eggs were collected and transferred individually to bags of TNT fabric; (C) these bags were immersed for 5 minutes in dilutions of $70 \%$ ethanolic extract of T. patula; (D-E) the bags were dried at room temperature and taken to BOD $\left(27-28^{\circ} \mathrm{C}, 70-80 \% \mathrm{RH}\right.$, photoperiod $\left.12 / 12 \mathrm{~h}\right)$, (F) After 3 weeks, living and dead larvae were counted. 
Table 1 List of the phenolic compounds identified in Tagetes patula by LC/ESI-IT-MS

\begin{tabular}{lccc}
\hline Compound & Peak & [M-H] & Product ion scan fragments of [M-H] \\
\hline Kaempferol & 1 & 285 & 151,134 \\
Patuletin & 2 & 331 & 316 \\
Quercetin-3-O-pentoside & 3 & 433 & 316 \\
$\begin{array}{l}\text { Quercetin-3-O-glucoside (isoquercitrin) or } \\
\text { Quercetina-3-O-galactoside (hyperoside) }\end{array}$ & 4 & 463 & 301 \\
$\begin{array}{l}\text { Patuletin-7-O-glucoside (patulitrin) or } \\
\text { 6-O-methyl-quercetin-3-O-glucoside }\end{array}$ & 5 & 493 & 331,316 \\
Quercetin-3-O-rhamnosyl-O-xyloside & & 579 & 447,301 \\
Quercetin-3-O-di-rhamnoside & 6 & 593 & 447,301 \\
Quercetin-3-O-glycosyl-7-O-rhamnosyl & 7 & 609 & 447,301 \\
Quercetin-3-O-rhamnosyl-7-O-glycosyl & $8 a$ & 609 & 463,301 \\
Kaempferol-3-O-di-hexoside & $8 b$ & 609 & 447,285 \\
Quercetin-3-O-hexoside-galloyl & $8 c$ & 615 & 463,301 \\
Kaempferol-3-O-rhamnoside-galloyl & 9 & 729 & 583,431
\end{tabular}

Peak 2 showed the signal of a deprotonated molecule $[\mathrm{MH}]^{-}$at $m / z$ 331. The second order fragmentation of precursor ion of $m / z 331$ generated the ion product $m / z$ $316\left[\mathrm{M}-\mathrm{CH}_{3}-\mathrm{H}\right]^{-}$. These data, together with literature references [43], allowed identification of the compound as patuletin.
Peak 3 exhibited the signal of a deprotonated molecule $[\mathrm{MH}]^{-}$at $m / z$ 433. The second order fragmentation generated the ion product $m / z 316$ [M-H-132] ${ }^{-}$, corresponding to loss of one pentose unit, suggesting it was quercetin-3-O-pentoside, compatible with quercetin3-O-xylose isolated in T. maxima [43].

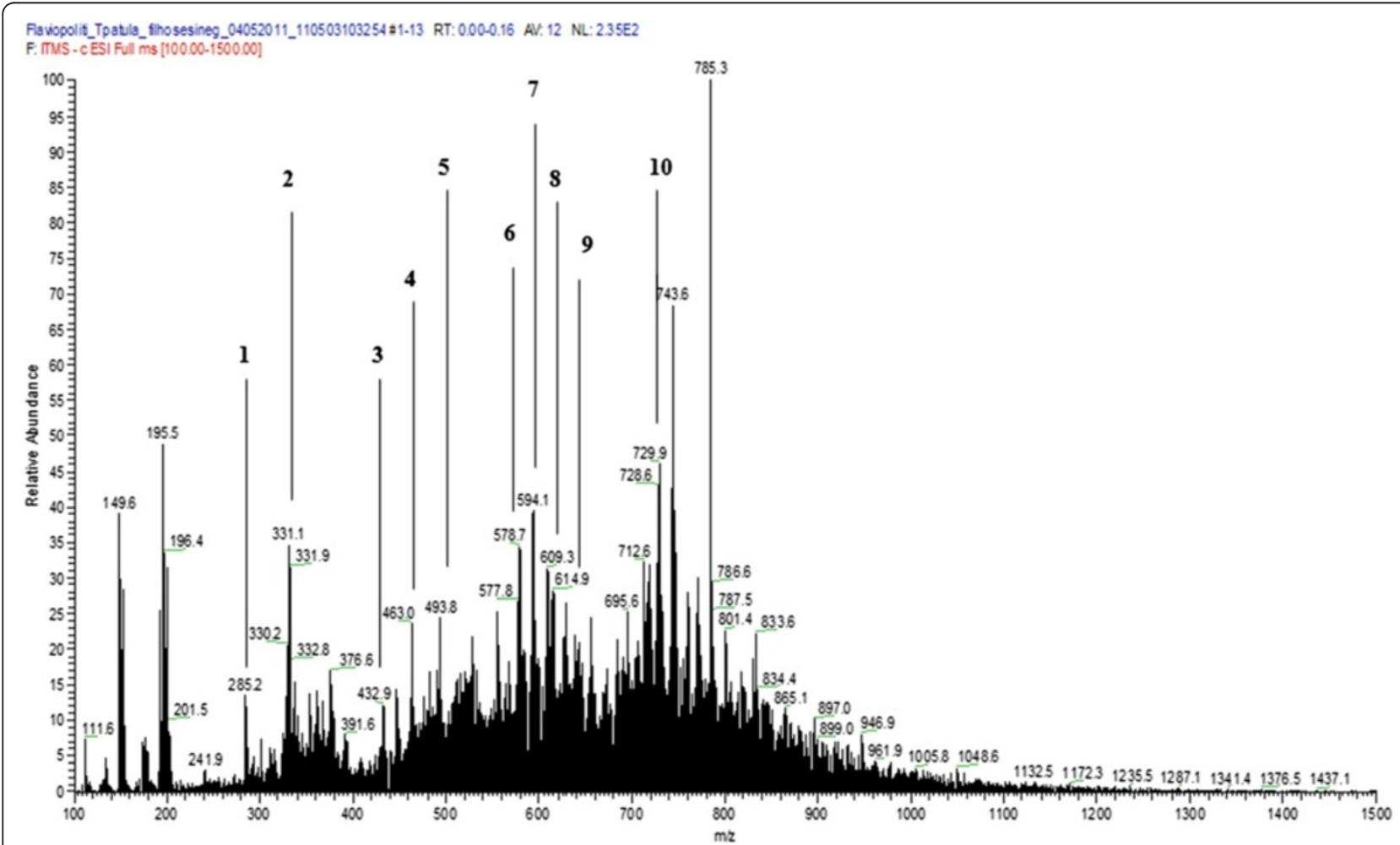

Figure 2 Chromatogram analysis by LC/FIA-ESI-IT-MS of $70 \%$ ethanolic extract of the aerial parts from $T$. patula. To spectrometric conditions detailed see the text. 
Peak 4 presented the signal of a deprotonated molecule $[\mathrm{MH}]^{-}$at $m / z 463$. The second order fragmentation generated the ion product $m / z 301$ [M-H-162]', corresponding to loss of one hexose unit, suggesting it was quercetin-3-O-glucoside (isoquercitrin) or quercetin-3-O-galactoside (hyperoside).

Peak 5 exhibited the signal of a deprotonated molecule $[\mathrm{MH}]^{-}$at $m / z$ 493. The second order fragmentation gen-

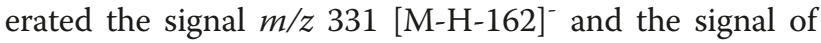
$\mathrm{m} / z 316[\mathrm{M}-\mathrm{CH} 3-\mathrm{H}]^{-}$, suggesting, according to data from the literature [43], that the compound could be patuletin-7-O-glucoside (patulitrin) or 6-O-methyl-quercetin-3-O-glucoside.

Peak 6 signal showed the signal of a deprotonated molecule $[\mathrm{MH}]^{-}$at $m / z 579$. The second order fragmentation with precursor ion at $\mathrm{m} / z 579$ generated the signal of $m / z 447$ [M-H-132] $]^{-}$, attributed to the loss of a xylose unit. Fragmentation of the ion at $m / z 447$ generated the signal $m / z 301$ [M-H-146] $]^{-}$, corresponding to loss of one deoxyhexose unit (e.g. rhamnnose). Considering the sequence the loss of sugars led to the proposal that the structure was of quercetin-3-O-rhamnosyl$\mathrm{O}$-xyloside for this substance.

Peak 7 exhibited the signal of a deprotonated molecule $[\mathrm{MH}]^{-}$at $m / z$ 593. The second order fragmentation generated the signals $m / z 447[\mathrm{M}-\mathrm{H}-146]^{-}$and $m / z 301$ [M-H-146] $]^{-}$, corresponding to the loss of two deoxyhexose units in sequence, suggesting it was quercetin-3-Odi-rhamnoside.

Peak 8 showed the signal of a deprotonated molecule $[\mathrm{MH}]^{-}$at $m / z 609$. The second order fragmentation generated three possibilities: signals $m / z \quad 447$ [M-H-162] and $m / z 301$ [M-H-146] $]^{-}$, corresponding to successive loss of a hexose unit and a deoxyhexose unit, suggesting it was quercetin-3-O-glycosyl-7-O-ramnosyl; signals $\mathrm{m} / z$ $463[\mathrm{M}-\mathrm{H}-146]^{-}$and $m / z 301$ [M-H-162] $]^{-}$, corresponding to successive loss of a deoxyhexose unit and a hexose unit, suggesting it could be quercetin-3-O-ramnosyl-7$O$-glucosyl and signals at $m / z 447$ [M-H-162] $^{-}$and $m / z$ $285[\mathrm{M}-142-\mathrm{H}]^{-}$, corresponding to successive loss of two hexose units, suggesting it could be kaempferol-3-Odi-hexoside.

Peak 9 exhibited the signal of a deprotonated molecule $[\mathrm{MH}]^{-}$at $m / z$ 615. The second order fragmentation generated signals $m / z \quad 463$ [M-H-152] and $m / z \quad 301$ [M-H-162]', corresponding to sequential loss of one galloyl unit and one hexose unit, suggesting it could be quercetin-3-O-hexoside-galloyl.

Peak 10 showed the signal of a deprotonated molecule $[\mathrm{MH}]^{-}$at $m / z$ 729. The second order fragmentation generated signals at $m / z 583$ [M-H-146] $]^{-}$and $m / z 431$ [M-H-152] $]^{-}$, relating to sequential losses of one rhamnose unit and one galloyl unit. These data suggest that the compound may be kaempferol-3-O-rhamnosidegalloyl.

Mortality of engorged adult females of $R h$. sanguineus subjected to $70 \%$ ethanolic extract was very low. There was only 1 death in the $12.5 \mathrm{mg} / \mathrm{mL}$ group (5\%), 1 death in the $25.0 \mathrm{mg} / \mathrm{mL}$ group (5\%), 2 deaths in the $50.0 \mathrm{mg} /$ $\mathrm{mL}$ group (10\%) and 1 death in the $100.0 \mathrm{mg} / \mathrm{mL}$ group (5\%). With this reduced number of deaths, the $\mathrm{LC}_{50}$ was not estimated (lethal concentration to $50 \%$ of organisms), because a very high value would be obtained, probably toxic to dogs and unattractive from a commercial standpoint. Table 2 shows the values of the percentage inhibition of egg laying, referring to the average of two assays.

Table 2 reveals that there was an increased percentage inhibition of egg laying at the lowest concentrations $(12.5$ and $25.0 \mathrm{mg} / \mathrm{ml}$ ) until $50.0 \mathrm{mg} / \mathrm{mL}$, from which the increase of concentration resulted in decreased activity to about half, showing a mathematical pattern expressed by the following equation: $y=-0.006 \mathrm{x}^{2}+$ $0.787 x-2.663\left(R^{2}=0.964\right)$, where $y=$ percentage of

Table 2 Index of egg laying and percentage of egg laying inhibition in females of Rhipicephalus sanguineus

\begin{tabular}{|c|c|c|c|c|}
\hline Samples & Weight of the Ticks (g) & Weight of the Eggs (g) & $\mathrm{IE}^{1}$ & Egg Laying Inhibition (\%) \\
\hline $\mathrm{AP}_{\mathrm{EtOH} 70 \%}$ & $0.1947^{a}$ & $0.1133^{a}$ & $0.5815^{a}$ & $7.0794^{b}$ \\
\hline$(12.5 \mathrm{mg} / \mathrm{mL})$ & $( \pm 0.010)$ & $( \pm 0.010)$ & $( \pm 0.024)$ & $( \pm 3.414)$ \\
\hline $\mathrm{AP}_{\mathrm{EtOH} 70 \%}$ & $0.1841^{a}$ & $0.1032^{a}$ & $0.5625^{a}$ & $11.4363^{b}$ \\
\hline$(25.0 \mathrm{mg} / \mathrm{mL})$ & $( \pm 0.028)$ & $( \pm 0.011)$ & $( \pm 0.025)$ & $( \pm 1.114)$ \\
\hline $\mathrm{AP}_{\mathrm{EtOH} 70 \%}$ & $0.1858^{a}$ & $0.0932^{\mathrm{a}}$ & $0.5024^{a}$ & $21,5088^{c}$ \\
\hline$(50.0 \mathrm{mg} / \mathrm{mL})$ & $( \pm 0.020)$ & $( \pm 0.008)$ & $( \pm 0.009)$ & $( \pm 2.151)$ \\
\hline $\mathrm{AP}_{\mathrm{EtOH} 70 \%}$ & $0.1822^{\mathrm{a}}$ & $0.1011^{\mathrm{a}}$ & $0.5577^{\mathrm{a}}$ & $12.0528^{b}$ \\
\hline$(100.0 \mathrm{mg} / \mathrm{mL})$ & $( \pm 0.045)$ & $( \pm 0.020)$ & $( \pm 0.023)$ & $( \pm 1.665)$ \\
\hline Triton-X-100 & $0.1768^{\mathrm{a}}$ & $0.1120^{\mathrm{a}}$ & $0.6338^{a}$ & $0.0^{\mathrm{a}}$ \\
\hline$(1.25 \%, v / v)$ & $( \pm 0.004)$ & $( \pm 0.004)$ & $( \pm 0.039)$ & $( \pm 0.0)$ \\
\hline
\end{tabular}

${ }^{1}$ IE: index of egg laying; values with the same superscript letters within a column do not show statistically significant differences by Sheffé, Tukey-Kramer and Neuman-Keuls tests $(p<0.05)$. The results represent the mean of two assays. 
inhibition of egg laying and $x=$ concentration of test sample. There were no statistically significant differences between the weight of the animals and their egg weights, avoiding bias in the results.

The percentage hatching of larvae was calculated assuming that $1.0 \mathrm{~g}$ of eggs correspond to approximately 20,000 larvae, mean value obtained from egg masses (without any chemical treatments) presenting hatching rate above 95\%. Considering this, and based on the weight of eggs laid per treatment, the expected number of hatched larvae was obtained. Counting the total number of larvae per glass tube, provided the actual number of hatched larva and allowed an estimation of the percentage of larvae hatching. Table 3 presents the results for the average of two assays ( \pm standard deviations) of reproductive efficiency calculating (RE) and product efficiency (PE) to dilutions of the $70 \%$ ethanolic extract of the aerial parts of $T$. patula $\left(\mathrm{AP}_{\mathrm{EtOH} 70 \%}\right)$. The greater effectiveness of the product was obtained to the extract $\mathrm{AP}_{\mathrm{EtOH} 70 \%}$ at a concentration of $50.0 \mathrm{mg} / \mathrm{mL} \quad(\mathrm{PE}=$ 42.45\%) and the lowest effectiveness at concentration of $12.5 \mathrm{mg} / \mathrm{mL}(\mathrm{PE}=25.29 \%)$. Regarding the percentage of hatching for all concentrations tested showed values below the control $(\mathrm{p}<0.05)$.

Figure 3 shows the results of the kinetic test of activity

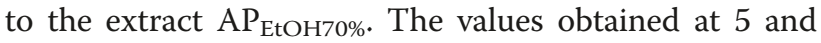
10 minutes were statistically similar, but differ from the values at 30 and 60 minutes, which were similar to each other. The results demonstrate that a longer immersion time of ticks in the extract solution does not potentiate its action, on the contrary, it decreases the percentage of egg laying. There were no reported cases of deaths of adult females after contact with $70 \%$ ethanolic extract from aerial parts of $T$. patula, in any groups tested.

Table 3 Values of reproductive efficiency and product efficiency of $70 \%$ ethanolic extract from Tagetes patula

\begin{tabular}{lcccc}
\hline Samples & $\mathbf{W}_{\text {eggs }}^{1}(\mathbf{g})$ & $\mathbf{H}_{\text {eggs }}^{2}(\%)$ & $\mathbf{R E}^{3}$ & $\mathbf{P E}^{\mathbf{4}}(\%)$ \\
\hline Triton-X-100 & $0.1120^{\mathrm{a}}$ & $92.0^{\mathrm{a}}$ & $210569.4^{\mathrm{a}}$ & - \\
$(1.25 \%, \mathrm{~V} / \mathrm{v})$ & $( \pm 0.004)$ & $( \pm 2.828)$ & $( \pm 7989.45)$ & \\
$\mathrm{AP}_{\text {EtOH70\% }}$ & $0.1133^{\mathrm{a}}$ & $71.42^{\mathrm{b}, \mathrm{c}}$ & $157525.71^{\mathrm{b}}$ & $25.29^{\mathrm{a}}$ \\
$(12.5 \mathrm{mg} / \mathrm{mL})$ & $( \pm 0.010)$ & $( \pm 3.818)$ & $( \pm 17520.79)$ & $( \pm 5.486)$ \\
$\mathrm{AP}_{\text {EtOH70\% }}$ & $0.1094^{\mathrm{a}}$ & $57.04^{\mathrm{b}}$ & $123639.12^{\mathrm{b}}$ & $41.14^{\mathrm{a}}$ \\
$(25.0 \mathrm{mg} / \mathrm{mL})$ & $( \pm 0.020)$ & $( \pm 5.798)$ & $( \pm 10222.45)$ & $( \pm 7.087)$ \\
$\mathrm{AP}_{\text {EtOH70\% }}$ & $0.9875^{\mathrm{a}}$ & $61.89^{\mathrm{b}, \mathrm{c}}$ & $121167.47^{\mathrm{b}}$ & $42.45^{\mathrm{a}}$ \\
$(50.0 \mathrm{mg} / \mathrm{mL})$ & $( \pm 0.016)$ & $( \pm 6.639)$ & $( \pm 6931.52)$ & $( \pm 3.291)$ \\
$\mathrm{AP}_{\text {EtOH70\% }}$ & $0.1011^{\mathrm{a}}$ & $76.83^{\mathrm{c}}$ & $154654.66^{\mathrm{b}}$ & $26.55^{\mathrm{a}}$ \\
$(100.0 \mathrm{mg} / \mathrm{mL})$ & $( \pm 0.020)$ & $( \pm 3.323)$ & $( \pm 25441.67)$ & $( \pm 12.082)$ \\
\hline
\end{tabular}

${ }^{1} \mathrm{~W}_{\text {eggs: }}$ total weight of eggs laid; ${ }^{2} \mathrm{H}_{\text {eggs: }}$ percentage of hatching of eggs laid; ${ }^{3}$ RE: reproductive efficiency, ${ }^{4} \mathrm{PE}$ : efficiency of the product (percentage). Values with the same superscript letters within a column do not showed statistically significant differences by Tukey and Neuman-Keuls tests $(p<0.05)$.
Table 4 shows the results of Larval Immersion Test. It can be observed that at concentrations of $50.0 \mathrm{mg} / \mathrm{mL}$ and $100.0 \mathrm{mg} / \mathrm{mL}$, there was approximately $100 \%$ killing of the larvae sampled. Even at the lowest concentration $(12.5 \mathrm{mg} / \mathrm{mL})$, the extract showed efficiency above $70 \%$.

The larval $\mathrm{IC}_{50}$ was calculated from the probit analysis (Finney method) with the mortality rate data, obtaining the value of $7.43 \mathrm{mg} / \mathrm{mL}$, with $95 \%$ level of significance (Table 5).

\section{Discussion}

The use of natural products in the control of brown dog tick $R h$. sanguineus has been the focus of research in many countries, especially with the increased resistance that these organisms present to commercial acaricides [14]. The main mechanisms used by resistant ticks to survive against acaricides are: reduction of the penetration rate of the product by changing the outer tegument; changes in metabolism, storage and excretion of the acaricide and changes of the site of action of chemical products [46]. In Brazil, studies that use plant extracts or essential oils against these ticks have been increasingly recurrent, some of them showing promising results.

The coupling of liquid chromatography and mass spectrometry is often used to characterize the chemical constituents of plant extracts. The mass spectrometer is considered as a universal detector, and thus the union brings a time saving element in the analysis of a complex matrix, because it avoids the isolation of its chemical constituents. Besides the chromatographic separation and the information on the molecular weight of substances, fragments of the molecules in question are also obtained, which are important for the structural elucidation of different classes of secondary metabolites [47]. Due to the high sensitivity, this system can detect minor compounds that have been isolated by standard phytochemical techniques [48]. The second order fragmentation (MS/MS) for each of the most representative ions led to the identification of $\mathrm{O}$-glycosylated flavonoids. In this type of flavonoid the $\mathrm{O}-\mathrm{C}$ bond is more susceptible to cleavage. The break and concomitant rearrangement of the hydroxyl hydrogen, leads to removal of monosaccharides, with losses of 176 mass units (uronic acid), 162 mass units (hexose), 146 mass units (deoxyhexose) or 132 mass units (pentose), allowing determination of the sequence of carbohydrates present in the aglycones [49]. In this work, when compared to positives, the negative mode led to results more elucidative to obtain the chemical composition of the extract of $T$. patula. Thus, although the positive mode has been evaluated, only the results in negative mode were presented, giving a total of 12 possible compounds in the constitution of the $70 \%$ ethanolic extract of the aerial parts from $T$. patula. 


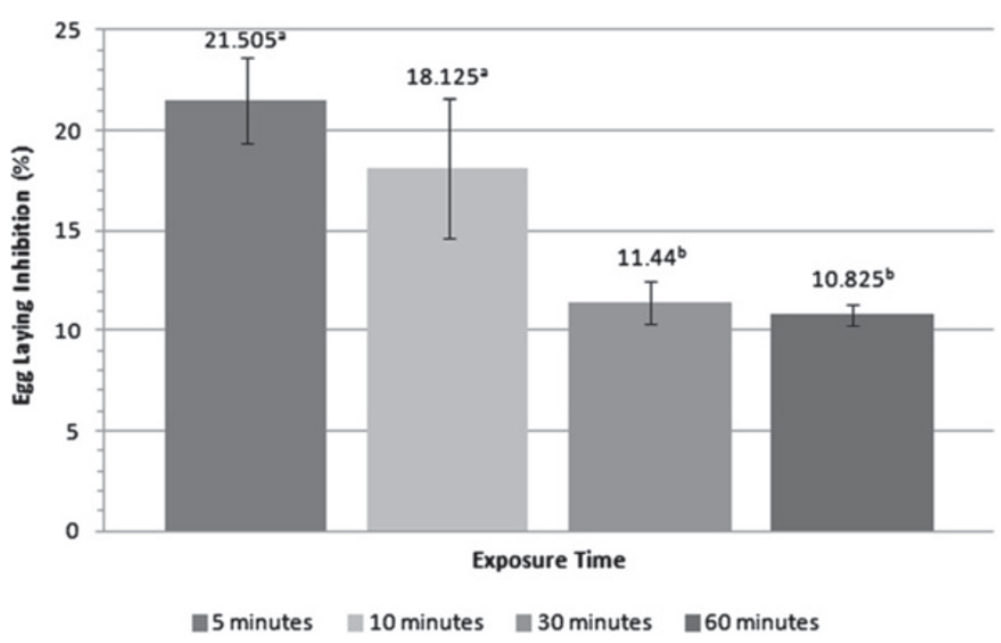

Figure 3 Action of $70 \%$ ethanolic extract from aerial parts of $T$. patula $(50.0 \mathrm{mg} / \mathrm{mL})$ in engorged female adult of Rh. sanguineus in the Adult Immersion Test for 5, 10, 30 and 60 minutes. Values with the same superscript letters do not show statistically significant differences by Tukey and Neuman-Keuls tests $(p<0.05)$.

These substances are in agreement with records from the literature, which describe the presence of phenolic compounds in various species of Tagetes [41-43, 50-52].

In this study, the immersion test of engorged adult $R h$. sanguineus showed no significant rates of death, occurring only in a few isolated cases in the replicates of each test. The most effective concentration tested was $50.0 \mathrm{mg} / \mathrm{mL}$, showing a percentage of inhibition of egg laying of $21.50 \%$. No previous reports testing natural plant extractives against engorged adult females of $R h$. sanguineus were found in the literature, precluding comparison with the results presented in this study, making it the pioneer. In a study with Riphicephalus (Boophilus) microplus, Ribeiro et al. [53] found as best result of percentage of egg laying inhibition the value of $19.2 \%$ for hexane extract of Hypericum polyanthemum (Guttiferae) $(25.0 \mathrm{mg} / \mathrm{mL})$. In another investigation, Ribeiro et al. [34] found values of percentage of egg laying inhibition of $R$. (Bophilus) microplus ranging between $11.7 \%$ and $14.6 \%$, using hexane extract of Calea serrata (Asteraceae).

The efficacy of the extracts was determined according to estimated reproduction calculation proposed by Drummond et al. [36]. The reproductive rate is influenced by several factors, the main ones being the temperature and relative humidity. In in vitro experiments these factors are controlled, which means that the results obtained are only due to the treatments. The analysis of variance (ANOVA) shows that the values of PE showed no statistically significant differences between groups. Furthermore, the results presented in Table 2 revealed a pattern of action of samples. It was found that there is similarity in the percentage of egg hatchability and in the product efficiency between extreme dilutions $(12.5 \mathrm{mg} / \mathrm{mL}$ and $100.0 \mathrm{mg} / \mathrm{mL})$ and between the intermediate dilutions $(25.0 / \mathrm{mL}$ and $50.0 \mathrm{mg} / \mathrm{mL})$. Thus, it

Table 4 Larval mortality rate of Rhipicephalus sanguineus front dilutions of $70 \%$ ethanolic extract of Tagetes patula

\begin{tabular}{|c|c|c|c|}
\hline Samples & Number of living larvae & Number of death larvae & (\%) Mortality ${ }^{1}$ \\
\hline \multirow[t]{2}{*}{ Distilled Water } & $145.33^{\mathrm{a}}$ & $17.00^{\mathrm{a}}$ & $10.48^{\mathrm{a}}$ \\
\hline & $( \pm 24.110)$ & $( \pm 2.645)$ & $( \pm 0.342)$ \\
\hline $\mathrm{AP}_{\mathrm{EtOH} 70 \%}$ & $35.66^{b}$ & $107.66^{\mathrm{b}}$ & $72.26^{b}$ \\
\hline$(12.5 \mathrm{mg} / \mathrm{mL})$ & $( \pm 6.429)$ & $( \pm 16.072)$ & $( \pm 0.628)$ \\
\hline $\mathrm{AP}_{\mathrm{EtOH} 70 \%}$ & $46.33^{b}$ & $134.00^{b}$ & $71.35^{b}$ \\
\hline$(25.0 \mathrm{mg} / \mathrm{mL})$ & $( \pm 8.020)$ & $( \pm 19.697)$ & $( \pm 1.344)$ \\
\hline $\mathrm{AP}_{\mathrm{EtOH} 70 \%}$ & $0.33^{c}$ & $178.33^{c}$ & $99.78^{c}$ \\
\hline$(50.0$ mg/mL) & $( \pm 0.577)$ & $( \pm 17.897)$ & $( \pm 0.367)$ \\
\hline $\mathrm{AP}_{\mathrm{EtOH} 70 \%}$ & $0.33^{c}$ & $108.666^{\mathrm{b}}$ & $99.72^{c}$ \\
\hline (100.0 mg/mL) & $( \pm 0.577)$ & $( \pm 27.006)$ & $( \pm 0.472)$ \\
\hline
\end{tabular}

${ }^{1}$ The mortality rate was calculated using Abbott's formula, due to the mortality rate in the control group was close to $10.0 \%$. Values with the same superscript letters within a column do not show statistically significant differences by Sheffé, Tukey-Kramer and Neuman-Keuls tests ( $p<0.05)$. The values are the mean of three assays, \pm the standard deviation. 
Table 5 Lethal concentrations of $70 \%$ ethanolic extract of Tagetes patula in larvae of Rhipicephalus sanguineus

\begin{tabular}{lcc}
\hline $\mathbf{L C}^{\mathbf{1}}$ (Percentile) & $\mathbf{L C} \mathbf{A P}_{\mathbf{A}}^{\mathbf{2}}(\mathbf{m g} / \mathbf{m L})$ & Level of $\mathbf{9 5 \%}$ of significance \\
\hline $\mathrm{LC}_{01}$ & 0.51 & $(0.29-0.77)$ \\
$\mathrm{LC}_{10}$ & 1.70 & $(1.57-2.24)$ \\
$\mathrm{LC}_{25}$ & 3.42 & $(3.34-4.12)$ \\
$\mathrm{L} C_{50}$ & 7.43 & $(7.42-7.68)$ \\
$\mathrm{L} C_{90}$ & 32.51 & $(32.45-37.39)$ \\
$\mathrm{L} C_{95}$ & 49.40 & $(49.35-55.19)$ \\
$\mathrm{L} C_{99}$ & 108.25 & $(108.19-123.67)$ \\
\hline
\end{tabular}

Chi-square $\left(X^{2}\right)=4.2096 ; p<0.05 ; p$-level $=0.1219 ;{ }^{1}$ LC: lethal concentration percentile; ${ }^{2} \mathrm{LC}_{\mathrm{AP}}$ : lethal concentration values of $70 \%$ ethanolic extract of aeria parts of $T$. patula calculated from the interpolation of the mortality results, by probit analysis (Finney method).

can be suggested that the efficiency in the inhibition of posture and/or hatching of the eggs is dose-dependent, i.e., from an optimal concentration, the inhibition rates tend to decay relatively. Overall, the $70 \%$ ethanolic extract of the aerial parts of $T$. patula $\left(\mathrm{AP}_{\mathrm{EtOH} 70 \%}\right.$ ) to $50.0 \mathrm{mg} / \mathrm{mL}$ was the most efficient, with a value of $\mathrm{PE}=42.45 \%$. BroglioMicheletti et al. [54] obtained values of product efficiency ranging between $18.35 \%$ to $2 \%$ ethanolic fraction of leaves of Cymbopogon citratus (Poaceae) and 59.24\% to $2 \%$ ethanolic fraction of flowers of Syzygium malaccensis (Myrtaceae).

When the exposure time of the ticks in the solutions tested was varied, statistically significant differences between the minimum and maximum were found. Interestingly, the percentage of egg laying inhibition of the group immersed for 5 minutes was almost twice that found in the group immersed for 60 minutes $(21.5 \%$ and $10.82 \%$, respectively). Further study of the mechanism of action of the extract $\mathrm{AP}_{\mathrm{EtOH} 70 \%}$ should be conducted to explain this finding, however, it can be suggested that 5 minutes is sufficient to obtain the results reported here and increments in the immersion time does not enhance its effectiveness.

Larval immersion tests showed very promising results. The $70 \%$ ethanolic extract of aerial parts of $T$. patula at $50.0 \mathrm{mg} / \mathrm{mL}$ and $100.0 \mathrm{mg} / \mathrm{mL}$ had mortality rates close $100 \%$. Even at the lowest concentration $(12.5 \mathrm{mg} / \mathrm{mL})$, the extract showed mortality rates higher than $70 \%$. Ribeiro et al. [53] obtained similar results, however, against Rh. (Boophilus) microplus. Using methanolic extract of Hypericum polyanthemum in concentrations of 50.0, 25.0, 12.5 and $6.25 \mathrm{mg} / \mathrm{ml}$ were obtained mortality rates of $100 \%, 96.7 \%( \pm 1,5), 84.7 \%( \pm 3.5)$ and $52.7 \%$ $( \pm 2.5)$, respectively.

In this study, $70 \%$ ethanolic extract of the aerial parts of $T$. patula presented larval $\mathrm{LC}_{50}$ and larval $\mathrm{LC}_{95}$ of $7.43 \mathrm{mg} / \mathrm{mL}$ and $49.4 \mathrm{mg} / \mathrm{mL}$, respectively. Fernandes et al. [20], performing another type of assay, the classical larval packet test [39], found for ethanolic extract from stem bark of Magonia pubescens (Sapindaceae) $\mathrm{LC}_{50}$ and $\mathrm{LC}_{99}$ against larvae of $R h$. sanguineus of $1.50 \mathrm{mg} / \mathrm{mL}$ and $9.99 \mathrm{mg} / \mathrm{mL}$, respectively.

Briefly, in our study it was observed that low mortality rates caused by the tested extract on engorged adult forms and a lethal action close to $100 \%$ against larval forms. This discrepancy could be explained by the difference in the composition of the cuticle of both life stages of ticks. According Balashov [55], the cuticle of the ticks is formed by the outer layer, epicuticle (composed by waxes externally and by proteins internally) and the inner layer, called procuticle (protein and chitin). According Odhiambo [56], the layer of waxes or lipids is seen only from ecdysis in nymph and in greater quantity in the adult. Therefore, in engorged females, the solvents must first dissolve the lipid layer of the epicuticle in order to achieve the most polar layers of the cuticle, which consist of soluble proteins.

\section{Conclusions}

The $70 \%$ ethanolic extract of aerial parts of $T$. patula $50 \mathrm{mg} / \mathrm{ml}$ reduced egg laying in $21.5 \%$ and eliminated $99.78 \%$ of the larvae $\left(\mathrm{LC}_{50}=7.43 \mathrm{mg} / \mathrm{mL}\right)$, although it was not effective on mortality of engorged female adult of $R h$. sanguineus. Also it was determined that the best results were obtained with 5 minutes of immersion. Further studies should be conducted in order to verify the in vitro cytotoxicity of this extract, however, the results reported here are important because it is a pioneering investigation and has suggested a novel methodology using the larval packet test. If we consider the application of the product in the environment, we would completely eliminate one of the developmental stages of the ixodid Rh. sanguineus.

\section{Competing interests}

The authors declare that they have no competing interests.

\section{Authors' contributions}

FASP carried out the studies, the statistical analysis and drafted the manuscript. GMF provided the plant samples. AMA and BRS helped in maintaining the colony of ticks and preparation of experiments. MPJS, GHB and MICM participated in the design of the study with Rh. sanguineus and discussion of results. LCS and WV participated in the planning of chromatographic tests and discussion of data. RCLRP conceived of the study, and participated in its design and coordination, discussion of data, helped to draft the manuscript. All authors read and approved the final manuscript.

\section{Acknowledgements}

We thank the São Paulo Research Foundation (FAPESP) for financial support and University of Campinas (UNICAMP) by the partnership.

\section{Author details}

${ }^{1}$ Department of Drugs and Medicines, School of Pharmaceutical Sciences, UNESP - Univ Estadual Paulista, Rodovia Araraquara-Jaú, Km 01, SP, Araraquara CEP 14801-902, Brazil. ${ }^{2}$ Chemical, Biological and Agricultural Pluridisciplinary Research Center (CPQBA), UNICAMP - Campinas State University, SP, Campinas CP 6171, CEP 13081-970, Brazil. 'Department of Biology, Institute of Biosciences, UNESP - Univ Estadual Paulista, Avenida 24-A, 1515, Bairro Bela Vista, SP, Rio Claro CEP 13506-900, Brazil. " Department 
of Applied Immunology and Parasitology, Faculty of Veterinary Medicine, UFU - Federal University of Uberlândia, Avenida Pará 1720, MG, Uberlândia CP 593, CEP 38400-902, Brazil. ${ }^{5}$ Department of Veterinary Pathology, College of Agricultural and Veterinary Sciences, UNESP - Univ Estadual Paulista, Via de Acesso Professor Paulo Donato Castellane s/n, SP, Jaboticabal CEP 14884-900, Brazil. 'Department of Organic Chemistry, Chemistry Institute, UNESP - Univ Estadual Paulista, Rua Professor Francisco Degni 55, Bairro Quitandinha, SP, Araraquara CEP 14800-900, Brazil.

Received: 26 October 2012 Accepted: 4 December 2012

Published: 17 December 2012

\section{References}

1. Massard $\mathrm{CL}$, Fonseca AH: Carrapatos e doenças transmitidas, comuns ao homem e aos animais. A Hora Vet 2004, 135:15-23.

2. Guimarães JH, Tucci EC, Barros-Battesti DM: Ectoparasitos de importância veterinária. São Paulo: Editora Plêidade; 2001.

3. Pegram RG, Keirans JE, Clifford CM, Walker JB: Clarification of the Rhipicephalus sanguineus group (Acari, Ixodoidea, Ixodidae). II. Rh sanguineus (Latreille, 1806) and related species. Syst Parasitol 1987, 10:27-44

4. Smith RD, Sells DM, Stephenson EH, Ristic M, Huxoll DL: Development of Ehrlichia canis, causative agent of canine ehrlichiosis, in the tick Rhipicephalus sanguineus and its differentiation from a symbiotic rickettsia. Am J Vet Res 1976, 37(2):119-126.

5. Gothe R, Wegerot S, Walden R, Walden A: Epidemiology of Babesia canis and Babesia gibsoni infections in dogs in Germany. Kieintierpraxis 1989, 34(7):309-320.

6. Dantas-Torres F: The brown dog tick, Rhipicephalus sanguineus (Latreille, 1806) (Acari: Ixodidae): from taxonomy to control. Vet Parasitol 2008, 152(3-4):173-185.

7. Swango LJ, Bankemper KW, Kong LI: Infecções bacterianas, riquetsiais, protozoais e outras. In Tratado de medicina veterinária interna: moléstias do cão e do gato. 3rd edition. Edited by Ettinger SJ. São Paulo: Manole; 1992:277-311.

8. Alcaíno H, Gorman T, Acosta P, Fredes F: Evaluación de cinco esquemas de control con cipermetrina del Rhipicephalus sanguineus en la Región Metropolitana de Chile. Arch Med Vet 1995, 27:45-51.

9. Franc M, Cadiergues MC: Activity of a deltamethrin shampoo against Ctenocephalides felis and Rhipicephalus sanguineus in dogs. Vet Parasitol 1999, 81:341-346.

10. Jernigan $A D$, Mctier $T L$, Chieffo $C$, Thomas $C A$, Krautmann MJ, Hair JA, Young DR, Wang C, Rowan TG: Efficacy of selamectin against experimentally induced tick (Rhipicephalus sanguineus and Dermacentor variabilis) infestations on dogs. Vet Parasitol 2000, 91:359-375.

11. Otranto D, Lia RP, Cantacessi C, Galli G, Paradies P, Mallia E, Capelli G: Efficacy of a combination of imidacloprid $10 \%$ /permethrin $50 \%$ versus fipronil 10\%/(S)-methoprene 12\%, against ticks in naturally infected dogs. Vet Parasitol 2005, 130:293-304.

12. World Health Organization: Pesticides and their Application for the Control of Vectors and Pests of Public Health Importance. 6th edition. Geneva; 2006.

13. Roma GC, Furquim KCS, Bechara GH, Camargo-Mathias MI: Permethrininduced morphological changes in oocytes of Rhipicephalus sanguineus (Acari: Ixodidae) semi-engorged females. Food Chem Toxicol 2010, 48:825-830

14. Miller RJ, George JE, Guerrero F, Carpenter L, Welch JB: Characterization of acaricide resistance in Rhipicephalus sanguineus (Latreille) (Acari: Ixodidae) collected from the Corozal Army Veterinary Quarantine Center. Panama. J Med Entomol 2001, 38:298-302.

15. Paião JCV, Monteiro AC, Kronka S: Susceptibility of the cattle tick Boophilus microplus (Acari: Ixodidae) to isolates of the fungus Beauveria bassiana. W J Microbiol Biotechnol 2001, 17(3):245-251.

16. Dantas-Torres F, Figueredo LA, Faustino MAG: Ectoparasitos de cães provenientes de alguns municípios da região metropolitana do Recife, Pernambuco, Brasil. Rev Bras Parasitol Vet 2004, 13(4):151-154.

17. Prette N, Monteiro AC, Garcia MV, Soares VE: Patogenicidade de isolados de Beauveria bassiana para ovos, larvas e ninfas ingurgitadas de Rhipicephalus sanguineus. Ciênc Rural 2005, 35(4):855-861.

18. Abdel-Shafy S, Zayed AA: In vitro acaricidal effect of plant extract of neem seed oil (Azadirachta indica) on egg, immature, and adult stages of
Hyalomma anatolicum excavatum (Ixodoidea: Ixodidae). Vet Parasitol 2002, 106:89-96.

19. Carroll JF, Maradufu A, Warthen JDJ: An extract of Commiphora erythraea: a repellent and toxicant against tick. Entomol Exp App/ 1989, 53:111-116.

20. Fernandes FF, D'Alessandro WBD, Freitas EPS: Toxicity of extract of Magonia pubescens (Sapindales: Sapindaceae) St. Hil. to control the brown dog tick, Rhipicephalus sanguineus (Latreille) (Acari: Ixodidae). Neotrop Entomol 2008, 37(2):205-208.

21. Arnosti A, Brienza PD, Furquim KCS, Chierice GO, Neto SC, Bechara GH, Sampieri BR, Camargo-Mathias Ml: Effects of Ricinus communis oil esters on salivary glands of Rhipicephalus sanguineus (Latreille, 1806) (Acari: Ixodidae). Exp Par 2011, 127:569-574.

22. Denardi SE, Bechara GH, Oliveira PR, Camargo-Mathias MI: Ultrastructural analysis of the oocytes of female Rhipicephalus sanguineus (Latreille, 1806) (Acari: Ixodidae) ticks subjected to the action of Azadirachta indica A. Juss (Neem). Ultrastruct Pathol 2012, 36(1):56-67.

23. Sampieri BR, Arnosti A, Nunes PH, Furquim KCS, Chierice GO, Camargo-Mathias MI: Ultrastructural changes in the ovary cells of engorged Rhipicephalus sanguineus female ticks treated with esters of ricinoleic acid from castor oil (Ricinus communis). Microsc Res Tech 2012, 75:683-690.

24. Yunes RA, Pedrosa RC, Cechinel-Filho V: Fármacos e fitoterápicos: a necessidade do desenvolvimento da indústria de fitoterápicos no Brasil. Quim Nova 2001, 24(1):147-152.

25. Gilman EF: University of Florida, Cooperative Extension Service, Institute of Food and Agricultural Sciences, Fact Sheet FPS-571: Tagetes patula French marigold. Florida; 1999

26. Massera PE, Rodriguez T, Giulietti AM: Thiophene production in transformed roots cultures of Tagetes filifolia. Biotec Lett 1998, 20(6):573-577.

27. Bano H, Ahmed SW, Azhar I, Ali MS, Alam N: Chemical constituents of Tagetes patula L. Pak J Pharm Sci 2002, 15(2):1-12.

28. Ivancheva S, Zdravkova M: Flavonoids in Tagetes patula. Fitoterapia 1993, 64:555-558.

29. Tarpo E: Patuletin isolation form Tagetes patula flowers. Farmasia 1967, 15:685-688.

30. Tarpo E: Isolation of patulitrine from the flowers of Tagetes patula. Farmasia 1968, 16:93-98.

31. Tarpo E: Isolation of quercetagetin from Tagetes patula flowers. Farmasia 1969, 17:739-744

32. Bhardwaj DK, Bisht MS, Uain SC, Metha CK, Sharma GC: Quercetagetin 5-methyl ether from the petal of Tagetes patula. Phytochemistry 1980, 19:713-714

33. Bechara GH, Szabó MPJ, Ferreira BR, Garcia MV: Rhipicephalus sanguineus in Brazil: feeding and reproductive aspects under laboratorial conditions. Rev Bras Parasitol Vet 1995, 4:61-66.

34. Ribeiro VLS, Avancini C, Gonçalves K, Toigo E, Von Poser G: Acaricidal activity of Calea serrata (Asteraceae) on Boophilus microplus and Rhipicephalus sanguineus. Vet Parasitol 2008, 151:351-354.

35. Sabatini GA, Kemp DH, Hughes S, Nari A, Hansen J: Tests to determine $\mathrm{LC}_{50}$ and discriminating doses for macrocyclic lactones against the cattle tick. Boophilus microplus. Vet Parasitol 2001, 95:53-62.

36. Drummond RO, Ernest SE, Trevino JL, Gladney WJ, Graham OH: Boophilus annulatus and Boophilus microplus: Laboratory test of insecticides. J Econ Entomol 1973, 66(1):130-133.

37. Shaw RD: Culture of an organophosphorus-resistant strain of Boophilus microplus (Can.) and an assessment of its resistance spectrum. Bull Entomol Res 1966, 53:563-578.

38. Abbott WS: A method of computing the effectiveness of an insecticide. J Econ Entomol 1925, 18:265-267.

39. FAO: Food and Agriculture Organization: Resistance management and integrated parasites control in ruminants. Guidelines, Module 1: Ticks Acaricide Resitance, Diagnosis, Management and Prevention. Rome; 2004:25-77.

40. Tereschuk ML, Riera MVQ, Guillermo RC, Abdala LR: Antimicrobial activity of flavonoids from leaves of Tagetes minuta. J Ethnopharmacol 1997, 56:227-232

41. Abdala LR: Flavonoids of the aerial parts from Tagetes lucida (Asteraceae) Biochem Syst Ecol 1999, 27:753-754

42. Abdala LR: Flavonoids of Tagetes stenophylla Robinson (Asteraceae) as taxonomic markers. Biochem Syst Ecol 2000, 28:717-718. 
43. Parejo I, Jáuregui O, Viladomat F, Bastida J, Codina C: Characterization of acylated flavonoid-O-glycosides and methoxylated flavonoids from Tagetes maxima by liquid chromatography coupled to electrospray ionization tandem mass spectrometry. Mass Spectrom 2004, 18:2801-2810.

44. Guinot P, Gargadennec A, Valette G, Fruchier A, Andary C: Primary flavonoids in marigold dye: extraction, structure, and involvement in dyeing process. Phytochem Anal 2008, 19:46-51.

45. Mabry TJ, Markham KG, Thomas MB: The Systematic identification of flavonoids. New York: Springer-Verlag Publication; 1970.

46. Furlong J: Booohilus microplus, o carrapato dos bovinos, Práticas de Manejo Sanitário em Bovinos de Leite. Juiz de Fora: EMBRAPA Gado de Leite - Área de Comunicação Empresarial; 2000:17-33.

47. Benavides A, Montoro P, Bassarello C, Piacente S, Pizza C: Catechin derivatives in Jatropha macrantha stems: characterisation and LC/ESI/ MS/MS quali-quantitative analysis. J Pharmac Biomed Anal 2006, 40:639-647.

48. Zhou S, Hamburger M: Application of liquid chromatographyatmospheric pressure ionization mass spectrometry in natural products analysis. Evaluation and optimization of electrospray and heated nebulizer interfaces. J Chromatogr 1996, 755:189-204.

49. Wolfender $\mathrm{J}$, Maillard M, Marston A, Hostettmann K: Mass spectrometry of underivatised naturally occurring glycosides. Phytochem Anal 1992, 3:193-214.

50. Abdala LR, Seeligmann P: Natural Distribution of Flavonoids in Tagetes minuta. Biochem Syst Ecol 1995, 23(5):567-568.

51. Abdala LR: Tagetes tenuifolia Cav. (Asteraceae): some chemosystematic implications of their flavonoids. Biochem Syst Ecol 2001, 29:861-863.

52. Abdala LR: Chemosystematic interpretations of the flavonoids identified in Tagetes gracilis (Asteraceae). Biochem Syst Ecol 2003, 31:323-325.

53. Ribeiro VLS, Toigo E, Bordignon SAL, Gonçalves K, Von Poser G: Acaricidal properties of extracts from the aerial parts of Hypericum polyanthemum on the cattle tick Boophilus microplus. Vet Parasitol 2007, 147:199-203.

54. Broglio-Micheletti SMF, Valente ECN, Souza LA, Dias NS, Araújo AMN Extratos de plantas no controle de Rhipicephalus (Boophilus) microplus (Canestrini, 1887) (Acari: Ixodidae) em laboratório. Rev Bras Parasitol Vet 2009, 18(4):44-48.

55. Balashov YS: Blood sucking ticks (Ixodidae) vectors of diseases of man and animals. Misc Pub Entomol Soc Am 1972, 8:161-376.

56. Odhiambo TR: Current themes in tropical science: physiology of ticks. Oxford: Pergamon; 1980

doi:10.1186/1756-3305-5-295

Cite this article as: Politi et al: Acaricidal activity of ethanolic extract from aerial parts of Tagetes patula L. (Asteraceae) against larvae and engorged adult females of Rhipicephalus sanguineus (Latreille, 1806). Parasites \& Vectors 2012 5:295.

\section{Submit your next manuscript to BioMed Central and take full advantage of:}

- Convenient online submission

- Thorough peer review

- No space constraints or color figure charges

- Immediate publication on acceptance

- Inclusion in PubMed, CAS, Scopus and Google Scholar

- Research which is freely available for redistribution 